\title{
PENGARUH IKLIM ORGANISASI TERHADAP TURNOVER INTENTION MELALUI KEPUASAN KERJA SEBAGAI VARIABEL INTERVENING PADA PT BANK SULSELBAR
}

\author{
Andi Caezar To Tadampali ${ }^{1}$, Abdurrahman Hadi ${ }^{2}$, Rudi Salam ${ }^{3}$ \\ ${ }^{1,2}$ Dosen Universitas Muhammadiyah Makassar \\ ${ }^{3}$ Universitas Negeri Makassar
}

\begin{abstract}
ABSTRAK
Penelitian ini bertujuan mengetahui pengaruh iklim organisasi secara langsung terhadap turnover intention dan secara tidak langsung melalui kepuasan kerja sebagai variabel intervening di PT Bank Sulselbar. Desain penelitian Path Analysis digunakan sebagai alat analisis untuk menentukan arah variabel yang diteliti serta menjustifikasi seberapa signifikan pengaruh variabel independen dan dependen baik secara langsung maupun tidak langsung melalui variable mediasi. Hasil penelitian menunjukkan bahwa variabel iklim organisasi berpengaruh positif signifikan terhadap kepuasan kerja karyawan secara langsung. Iklim organisasi berpengaruh negatif signifikan terhadap turnover intention secara langsung. Variabel kepuasan kerja terhadap turnover intention berpengaruh negatif signifikan terhadap turnover intention. Melalui mediasi kepuasan kerja secara tidak langsung iklim organisasi tetap berpengaruh negatif signifikan terhadap turnover intention. Orisinalitas: Pengelolaan personalia dan promosi karyawan yang berdasarkan kompetensi akan semakin memacu karyawan dalam berprestasi dan dapat meningkatkan kinerjanya. Dengan menempatkan salah satu variable sebagai mediasi dapat menghasilkan sesuatu yang berbeda dan penelitian ini dapat memberikan gambaran bagi manajer berkaitan dengan masalah pengambilan keputusan.
\end{abstract}

Kata Kunci: Budaya Organisasi, Gaya Kepemimpinan, Komitmen Organisasi, path Analysis

\section{PENDAHULUAN}

Dalam hubungannya dengan sumber daya manusia, dari berbagai penelitian yang telah dilakukan, perubahan kondisi lingkungan organisasi baik internal maupun eksternal secara langsung maupun tidak langsung dapat mempengaruhi iklim organisasi yang dapat menurunkan tingkat kepuasan kerja yang pada akhirnya dapat menimbulkan niat untuk pindah bagi karyawan (turnover intention) yang pada akhirnya dapat menimbulkan turnover yang sebenarnya.

Berbagai definisi tentang turnover diungkapkan oleh para peneliti. Turnover menurut Cotton \& Tuttle (1986), diartikan sebagai suatu perkiraan kemungkinan seorang individu akan tetap berada dalam suatu organisasi. Oleh karena itu menurut Maertz dan Campion (1998) dalam Samad (2006), proses identifikasi terhadap faktorfaktor yang mempengaruhi niat untuk pindah (turnover intention) menjadi suatu hal yang penting untuk dipertimbangkan dan menjadi suatu yang efektif untuk menurunkan angka turnover yang sebenarnya.

Untuk mengidentifikasi faktorfaktor yang mempengaruhi turnover intention, para peneliti telah menggali berbagai faktor yang mempengaruhi turnover intention tersebut, diantaranya penelitian yang dilakukan oleh 
Vandenberg \& Nelson (1999), yang mengemukakan bahwa komitmen organisasi dan kepuasan kerja sebagai prediktor munculnya turnover intention. Studi lain dilakukan oleh Igbaria \& Greenhaus (1992), mengindikasikan bahwa kepuasan kerja dan komitmen organisasi mempunyai pengaruhyang paling besar terhadap turnover intention.

Sehubungan dengan munculnya turnover intention, karyawan yang memiliki kepuasan kerja akan lebih produktif, memberikan kontribusi terhadap sasaran dan tujuan organisasi, dan pada umumnya memiliki keinginan yang rendah untuk keluar dari perusahaan (Harter, Schmidt, \& Hayes, 2002).

Turnover dapat berakibat fatal bagi organisasi karena mengalami kekurangan tenaga ahli pada pasar tenaga kerja dan menyebabkan biaya pendidikan yang tinggi bagi karyawan pemula (Igbaria dan Greenhaus, 1992). Penelitian yang dilakukan oleh Roberts, Coulson, dan Chonko (1999) dalam Mulki, et al. (2006) mununjukkan bahwa turnover tenaga pemasaran merupakan faktor yang utama terhadap bisnis.

Salah satu dari berbagai faktor yang perlu menjadi perhatian perusahaan untuk mengurangi angka turnover karyawan adalah bagaimana perusahaan mengelola iklim yang baik dan kondusif dalam aktivitas kerja karyawan dan adanya upaya untuk mengelola sumber daya manusia yang baik dan berkesinambungan untuk mengurangi tingkat turnover intention yang dapat dialami oleh karyawan.

Reichers dan Scheneider (1990) dalam Vardi (2001), mendefinisikan iklim sebagai suatu persepsi atau anggapan bersama mengenai kebijakan organisasi, pelaksanaan kebijakan dan prosedurprosedur baik formal maupun informal. Iklim sebagai suatu representasi dan tujuan-tujuan organisasi dan alat-alat dan cara-cara yang ditiru dan dijalankan untuk mencapai hasil yang diinginkan. Menurut Fey \& Beamish (2001) dalam konsep yang bersifat tradisional, iklim organisasi bertujuan untuk menggambarkan kondisi sepintas dari suatu organisasi dalam kurun waktu tertentu.

Kepuasan kerja diartikan sebagai sikap umum seseorang terhadap pekerjaannya atau dapat juga diartikan sebagai perbedaan antara jumlah imbalan/penghargaan yang diterima oleh karyawan dan jumlah seharusnya mereka dapatkan (Robbins, 2003). Menurut Locke (1976) dalam Desiana \& Soetjipto (2006) kepuasan kerja adalah suatu keadaan emosional positif dan menyenangkan yang dihasilkan dari penilaian pekerjaan atau pengalaman kerja. Menurut George dan Jones (2002) dalam Desiana \& Soetjipto (2006), kepuasan kerja adalah perasaan yang dimiliki oleh karyawan tentang kondisi tempat kerja mereka saat ini.

Hasil survei Price water house Coopers $(\mathrm{PwC})$ Indonesia terhadap industri perbankan di Indonesia menunjukkan keluar-masuk karyawan (turnover) di sektor ini mencapai $15 \%$. Tingginya angka tersebut disebabkan permintaan akan sumber daya manusia (SDM) di sektor ini masih tinggi, sementara pasokan yang tersedia minim. PwC mengklaim hasil survei ini menggambarkan $80 \%$ aset industri perbankan di Indonesia. Survei tersebut dilakukan dari Januari hingga Februari $2014 . \quad$ (Sumber: PricewaterhouseCoopers)

Penelitian ini memilih PT. Bank Sulselbar sebagai obyek penelitian didasarkan oleh tingkat turnover karyawan PT. Bank Sulselbar yang lebih rendah dari hasil survey PwC. Penelitian ini bertujuan mengetahui pengaruh iklim organisasi secara langsung terhadap turnover intention dan secara tidak langsung melalui kepuasan kerja sebagai variabel intervening di PT Bank Sulselbar. Berdasarkan hasil survei PwC diatas yang menunjukkan tingginya tingkat turnover sektor perbankan Indonesia, penelitian turnover intention karyawan disektor perbankan khususnya PT. Bank Sulselbar adalah hal yang sangat perlu untuk 
dilakukan untuk memprediksi seberapa besar faktor iklim organisasi dan kepuasan kerja mempengaruhi niat untuk pindah (turnover intention) karyawan dan memberikan masukan kepada perusahaan sebagai salah satu upaya untuk menekan angka turnover yang sebenarnya.

\section{TINJAUAN PUSTAKA}

\section{Iklim Organisai dan Kepuasan Kerja}

Iklim organisasi merupakan suatu keadaan atau ciri-ciri atau sifat-sifat yang menggambarkan suatu lingkungan psikologis organisasi yang dirasakan oleh orang yang berada dalam lingkungan organisasi tersebut. Iklim organisasi dipengaruhi oleh persepsi anggota yang ada pada organisasi tersebut. Dengan demikian apabila pegawai merasa bahwa iklim yang ada pada organisasi tempat ia bernaung cukup kondusif dan menyenangkan baginya untuk bekerja dengan baik, dan hal ini akan membuat pegawai tersebut merasa puas.

Dalam hubungannya dengan kepuasan kerja pegawai, menurut penelitian Rongga et al. (2001) mengemukakan bahwa ada hubungan yang positif antara iklim yang lebih berorientasi pada pekerja, lebih terbuka dan lebih bersifat konsultatif danpada umumnya dihubungkan dengan sikap yang lebih positif. Burke (1994) dalam Haryanti (2005) mengatakan bahwa manajemen persepsi pegawai melalui perubahan untuk menyatukan budaya, sistem penghargaan, iklim kelompok kerja, dan perilaku manajerial adalah masalah penting dalam upaya meningkatkan dan mengembangkan sistematika serta fungsi manajemen sumber daya manusia. Lebih lanjut Burke (1994) dalam Haryanti (2005) berpendapat bahwa iklim organisasi yang kondusif erat kaitannya dengan kepuasan kerja melalui persepsi terhadap pekerjaan itu sendiri.

Perilaku yang ditunjukkan oleh pimpinan dan anggota kelompok semuanya memiliki dampak pada sikap dan persepsi pegawai tentang pekerjaan dan organisasi mereka (Church, 1995). Pegawai yang merasakan kepuasan kerja lebih cenderung menjadi produktif dan untuk bertahan pada pekerjaan (Cohen, Likert dan Katz dalam Mc Nesse-Smith, 1996).

Rongga et. al. (2001) melakukan penelitian terhadap iklim organisasi dan kepuasan pelanggan dengan sampel para manajer di perusahaan kecil menjadi obyek penelitian dan pegawai sebagai pelanggan menjelaskan bahwa iklim organisasi mempunyai hubungan yang sangat kuat dengan kepuasan kerja. Penelitian lain yang memperkuat pendapat mengenai hubungan iklim organisasi dan kepuasan kerja adalah penelitian yang dilakukan oleh Friedlander dan Margulies (1969) yang berpendapat bahwa iklim organisasi mempunyai hubungan yang langsung terhadap kepuasan kerja. Penelitian serupa dilakukan oleh Downey dan Slocum (1975) menjelaskan hasil penelitiannya bahwa iklim organisasi saling berhubungan dengan kepribadian individu dalam mempengaruhi kepuasan kerja dan kinerja karyawan.

Dalam penelitian serupa mengenai iklim organisasi dalam hubungannya dengan kepuasan kerja, Mahajan, et al. (1984) mengemukakan adanya hubung anantara empat variabel iklim organisasi (closeness of supervision, influence indetermining standards, perceived role ambiquity, dan perceived role conflict) dengan kepuasan kerja. Dalam penelitian lain yang dilakukan Snyder (1990) dengan sampel pemimpin pelatih atletik pada 17 perguruan tinggi di California menemukan bahwa perilaku pemimpin pelatih atletik dan iklim organisasi mempunyai pengaruh yang langsung maupun tidak langsung terhadap kepuasan kerja para pelatih. Pendapat ini diperkuat oleh Batlis (1980) yang mengemukakan bahwa salah satu dimensi dari iklim organisasi yaitu performance reward dependence mempunyai hubungan yang signifikan dengan kepuasan kerja (job satisfaction). Studi yang sama dilakukan oleh 
Johannesson (1973), Downey, Hellriegel, Phelps, \& Slocum (1974), dan LaFollette \& Sims (1975) dalam Muchinsky (1977) menjelaskan adanya hubungan antara dimensi iklim organisasi dan dimensi kepuasan kerja.

\section{Kepuasan Kerja dan Turnover Intention}

Dalam rangka menguatkan penelitian tentang kepuasan kerja, Herzberg dalam Djati dan Khusaini (2003) berpendapat bahwa setiap orang menginginkan dua macam faktor kebutuhan, yaitu: pertama, kebutuhan akan kesehatan atau kebutuhan akan pemeliharaan. Hal ini berhubungan dengan hakikat manusia yang ingin memperoleh ketentraman lahiriah. Faktor-faktor pemeliharaan meliputi balas jasa, kondisi kerja fisik, kepastian pekerjaan, supervisi yang menyenangkan, mobil dinas, rumah dinas, dan bermacam-macam tunjangan lainnya. Hilangnya faktor pemeliharaan ini dapat menyebabkan timbulnya ketidakpuasan dan tingkat absensi karyawan serta turnover akan meningkat. Faktor-faktor pemeliharaan ini perlu mendapatkan perhatian yang wajar dari pimpinan agar kepuasan dan semangat kerja karyawan dapat ditingkatkan.

Disamping faktor pemeliharaan diatas, faktor kompensasi juga dipandang turut mempengaruhi produktivitas atau prestasi pekerja. Robbins (2003) menjelaskan bahwa pemberian kompensasi (rewards) seharusnya dikaitkan dengan prestasi kerja (performance). Sekalipun pemberian kompensasi telah didasarkan pada kriteria kinerja, apabila tenaga kerja mempersepsi rendah, hasilnya menjadi prestasi kerjanya rendah, menurunnya kepuasan kerja (job satisfaction) dan meningkatnya turnover dan absenteeism. Terjadinya turnover disebabkan oleh ketidak senangan karyawan terhadap pekerjaannya dan akan mencari alternatif kesempatan pekerjaan lain (Spector, 1997 dalam Jaramillo, et al., 2006).
Dalam penelitian yang dilakukan oleh Brown dan Peterson (1993); Griffeth, Hom, dan Gaertner (2000); Tett dan Meyer (1993) bahwa adanya hubungan yang signifikan antara kepuasan kerja dan niat untuk pindah. Penelitian-penelitian lain juga menunjukkan bahwa ketidakpuasan kerja merupakan penyebab utama munculnya turnover (Bretz, Boudreau, dan Judge, 1994; Fields et al., 2005). Penelitian serupa dilakukan oleh Babakus, et al. (1999) dan Low, et al. (2001) dalam Jaramillo, etal. (2006) menarik kesimpulan bahwa kepuasan kerja juga mempunyai hubungan yang tidak langsung terhadap niat untuk pindah. Pendapat yang sama disampaikan oleh Busch et al. (1998) dalam Hwang dan Huei Kuo (2006) menjelaskan bahwa seseorang yang relatif puas terhadap pekerjaannya akan tetap tinggal dalam perusahaan lebih lama, dan dapat menurunkan tingkat keluar masuk karyawan dan mengurangi keabsenan.

Penelitian yang dilakukan oleh Trevor (2001) dalam San Hwang dan HueiKuo (2006) menguatkan pendapat serupa dengan hasil yang nyata mengenai hubungan antara kepuasan kerja dengan turnover yang menunjukkan bahwa adanya hubungan yang negatif antara kepuasan kerja dan turnover. Penelitian lain dilakukan Carsten dan Spector (1987) menemukan adanya hubungan antara kepuasan kerja dengan turnover intention to quit. Pendapat serupa diperkuat oleh Hom dan Griffeth's (1991) yang memodifikasi model dari turnover dengan menggunakan model job satisfaction sebagai elemen kunci dalam pengambilan keputusan untuk tetap tinggal atau meninggalkan pekerjaan.

Studi lain yang dilakukan oleh Churchill, Ford dan Walker (1976) menemukan bahwa adanya hubungan yang negatif antara kepuasan kerja dan keluar masuknya (job turnover) tenaga kerja, ketidakpuasan pekerja akan membuat karyawan lebih suka untuk keluar dari perusahaan dan mencari pekerjaan lain. Susskind et al. (2000) dalam Chiu, et al. 
(2005) mengemukakan bahwa kepuasankerja mempunyai hubungan yang signifikan dan berhubungan negatif dengan niat untuk pindah.

Penelitian lain dilakukan oleh Chiu dan Francesco (2003) dalam Chiu, et al. (2005) yang mengindikasikan bahwa turnover intention individual mempunyai hubungan negatif dengan kepuasan kerja dan komitmen organisasi. Studi yang dilakukan oleh Abraham (1999) juga menguatkan pendapat yang sama dengan membuktikan adanya hubungan negatif yang kuat antara kepuasan kerja dan niatuntuk pindah dan setelah adanya usaha untuk meningkatkan kepuasan kerja, niat untuk pindah menurun dengan signifikan.

Penelitian yang dilakukan oleh Hezberg (1987) dalam Carmeli dan Weisberg (2006) menarik kesimpulan bahwa adanya hubungan negatif antara kepuasan kerja intrinsik dan kepuasan kerja ekstrinsik dengan niat untuk pindah. Thatcher dan Stepina (2001) dalam Ahuja, et al. (2007) menguatkan pendapat serupa dengan menggunakan variabel kepuasan kerja dan job utility untuk memprediksi niat karyawan untuk keluar dari organisasi (intention to quit).

\section{METODE PENELITIAN}

\section{Lokasi dan Rancangan Penelitian}

Penelitian ini dilaksanakan pada PT Bank Sulselbar di Kota Makassar. Penelitian ini merupakan penelitian penjelasan (explanatory research) yang membuktikan hubungan kausal antara variabel. Penelitian ini bertujuan untuk menunjukkan gambaran tentang hubungan antara iklim organisasi, dan kepuasan kerja dengan turnover intention.

\section{Populasi dan Sampel}

Populasi dalam penelitian ini adalah seluruh karyawan kantor pusat PT Bank Sulselbar Makassar berjumlah 169 orang. Sampel pada penelitian ini diambil dengan menggunakan metode sensus (sampling jenuh), dimana semua anggota populasi digunakan sebagai sampel. Seluruh kuesioner kembali dan 152 kuesioner dapat digunakan untuk pengolahan data.

\section{Metode Pengumpulan Data}

Teknik pengumpulan data yang digunakan adalah wawancara, observasi, kuesioner dan telaah dokumen yaitu 1). Kuesioner yaitu teknik pengumpulan data melalui angket berupa daftar pertanyaan yang ditujukan langsung kepada sejumlah responden terpilih yang berkaitan dengan analisis pengaruh pengembangan karier organisasi terhadap komitmen karyawan pada Kantor Pusat PT Bank Sulselbar. 2). Observasi, yaitu teknik pengumpulan data di mana peneliti terlibat langsung untuk mengamati analisis pengaruh pengembangan karier organisasi terhadap komitmen karyawan pada Kantor Pusat PT Bank Sulselbar. 3). Studi dokumentasi yaitu teknik pengumpulan data dengan cara mempelajari buku-buku maupun jurnal yang berkaitan dengan topik pembahasan.

\section{Analisis Data}

Sebelum melakukan analisis data, terlebih dahulu melakukan uji validitas dan reliabilitas data dengan SPSS21. Uji validitas dilakukan dengan membandingkan nilai $r$ hitung dengan $r$ tabel.Jika $r$ hitung lebih besar dari $r$ tabel dan nilai positif maka butir atau pernyataan atau indikator tersebut dinyatakan valid. Uji reliabilitas dihitung dengan menggunakan Cronbach Alpha > 0,60 yang menunjukkan instrumen yang digunakan reliabel.

Analisis statistik yang digunakan dalam penelitian ini adalah path analysis. Untuk menentukan besar pengaruh suatu variabel terhadap variabel lainnya diperlukan persyaratan sebagai berikut: pertama, hubungan antara variabel harus merupakan hubungan linear dan aditif; kedua, semua variabel residu tidak mempunyai korelasi satu sama lain; ketiga, 
pola hubungan antara variabel adalah rekursif, dan keempat, skala pengukuran baik pada variabel penyebab maupun variabel akibat sekurang-kurangnya adalah interval.

Selanjutnya koefisien path dapat dihitung dengan langkah kerja sebagai berikut; pertama, gambarkan diagram path untuk hubungan-hubungan variabel secara lengkap yang mencerminkan hipotesis konseptual yang diajukan. Kemudian hitung besarnya pengaruh (parameter struktural) antara suatu variabel penyebab dengan variabel akibat. Perhitungan ini didasarkan pada sub struktur hubungan antara buah variabel penyebab dengan sebuah variabel akibat.

Pengujian hipotesis dalam penelitian ini menggunakan analisis jalur (path analysis) dengan struktur jalur. (Gambar 1) Persamaan regresinya sebagai berikut:

a. $Y_{I}=a+\beta_{1} X_{1}+e_{1} \ldots \ldots \ldots \ldots \ldots \ldots \ldots$ (1)

b. $Y_{2}=a+\beta_{1} X_{1}+\beta_{2} Y_{1}+e$

Keterangan :

$\mathrm{X}_{1}$ : Iklim Organisasi

$\mathrm{Y}_{1}$ : Kepuasan Kerja

$\mathrm{Y}_{2}$ : Turnover Intention

B : Koefisien Regresi

e : error

Selanjutnya analisis data dengan menggunakan model analisis regresi berganda. Regresi digunakan untuk mengetahui atau menguji apakah ada pengaruh positif antara faktor-faktor yang berpengaruh terhadap turnover intention. Selanjutnya untuk melihat kemampuan variabel independen dalam menerangkan variabel dependen dapat diketahui dari besarnya koefisien determinasi berganda $\left(r^{2}\right)$. Dengan kata lain, nilai koefisien $\mathrm{r}^{2}$ digunakan untuk mengukur besarnya sumbangan variabel independen terhadap variasi variabel dependennya. Jika $\mathrm{r}^{2}$ diperoleh dari hasil perhitungan semakin besar atau mendekati 1 maka dapat dikatakan bahwa sumbangan dari variabel independen terhadap variasi variabel dependen semakin besar.
Selanjutnya untuk menentukan daerah penerimaan dengan menggunakan uji $t_{\text {tabel. }}$. Titik kritis yang akan dicari dari tabel distribusi $t$ dengan tingkat signifikansi atau level kesalahan $(\alpha) 0,05$ dengan derajat kebebasan (df). Adapun kriteria dalam menentukan pengaruh yang signifikan adalah jika $t_{\text {hitung }}>t_{\text {tabel }}$ atau nilai sig $<0,05$ berarti $\mathrm{H}_{0}$ ditolak, $\mathrm{H}_{\mathrm{a}}$ diterima berarti ada pengaruh antara variabel eksogen terhadap variabel endogen, jika $\mathrm{t}_{\text {hitung }}<\mathrm{t}_{\text {tabel }}$ atau nilai sig $>0,05$ berarti $\mathrm{H}_{0}$ diterima dan $\mathrm{H}_{\mathrm{a}}$ ditolak berarti tidak ada pengaruh antara variabel eksogen terhadap variabel endogen.

\section{HASIL DAN PEMBAHASAN}

\section{Uji Instrumen Penelitian}

Hasil uji validitas terlihat bahwa seluruh item pertanyaan pada instrumen pengukuran Iklim Organisasi $\left(\mathrm{X}_{1}\right)$, Kepuasan Kerja $\left(\mathrm{Y}_{1}\right)$ dan Turnover Intention $\left(\mathrm{Y}_{2}\right)$ memiliki hasil $\mathrm{r}$ hitung pada masing - masing item lebih besar dari $\mathrm{r}$ tabel $(0,1339)$, ini menunjukkan bahwa butir-butir kuesioner dalam penelitian ini valid.. Uji reliabilitas instrumen bahwa Iklim Organisasi $\left(\mathrm{X}_{1}\right)$, Kepuasan Kerja $\left(\mathrm{Y}_{1}\right)$ dan Turnover Intention $\left(\mathrm{Y}_{2}\right)$ menghasilkan koefisien Cronbach's Alpha $>0,6$ dengan demikian, dapat dinyatakan bahwa semua instrumen memiliki reliabilitas yang sangat baik untuk digunakan sebagai alat pengumpul data.

\section{Uji Asumsi Klasik}

Hasil Uji Asumsi Klasik yang dilakukan terhadap data yang digunakan dalam penelitian ini menunjukkan bahwa setiap data dari variabel yang digunakan dalam penelitan ini telah lulus Uji Asumsi Klasik yang meliputi: 1) Uji Multikolinearitas; 2) Uji Autokorelasi; 3) 5Uji Heteroskedastisitas; 4) Uji Normalitas. 


\section{Uji Koefisien Determinasi $\left(R^{2}\right)$}

Besarnya adjusted $R$ square untuk persamaan substruktur 1 adalah 0,305 atau sebesar $30,5 \%$ dimana variabel Iklim Organisasi mampu menjelaskan variabel Kepuasan Kerja 30,5\% dan sisanya 69,5\% dijelaskan oleh variabel lain diluar model yang tidak dimasukkan dalam analisis ini.

Besarnya adjusted $R$ square untuk persamaan substruktur 2 adalah 0,635 atau sebesar $63,5 \%$ dimana variabel Iklim Organisasi melalui Kepuasan Kerja mampu menjelaskan variabel Turnover Intention 63,5 \% dan sisanya 36,5\% dijelaskan oleh variabel lain diluar model yang tidak dimasukkan dalam analisis ini.

\section{Uji Kesesuaian Model (Uji F)}

Hasil uji statistik $\mathrm{F}$ menunjukkan bahwa persamaan substruktur 1 yang menguji pengaruh Iklim Organisasi terhadap Kepuasan Kerja memiliki nilai signifikansi sebesar 0,000 (lebih kecil dari nilai alpha 0,05). Hal ini menunjukkan bahwa terdapat pengaruh Iklim Organisasi terhadap Kepuasan Kerja.

Hasil uji statistik $\mathrm{F}$ menunjukkan bahwa persamaan substruktur 2 yang menguji pengaruh Iklim Organisasi melalui Kepuasan Kerja terhadap Turnover Intention memiliki nilai signifikansi sebesar $0,000<$ dari nilai alpha 0,05. Hal ini menunjukkan bahwa terdapat pengaruh Iklim Organisasi melalui Kepuasan Kerja terhadap Turnover Intention.

\section{Analisis Jalur}

Berdasarkan hasil pengolahan data yang telah diperoleh untuk model penelitian ini, maka digambarkan model diagram jalur penelitian ini. (Gambar 2)

Substruktur 1

Persamaan Substrukturalnya:

$$
\mathrm{Y}_{1}=0,289 \mathrm{X}_{1}+0,689
$$

Substruktur 2

Persamaan Substrukturalnya:

$$
Y_{2}=-0,433 X_{1}-0,628 Y_{1}+0,363
$$

$$
\begin{array}{ll}
\mathrm{X}_{1} & : \text { Iklim Organisasi } \\
\mathrm{Y}_{1} & : \text { Kepuasan Kerja } \\
\mathrm{Y}_{2} & : \text { Turnover Intention } \\
\mathrm{E}_{1}, \mathrm{E}_{2} & : \text { Error }=\sqrt{1-R^{2}}
\end{array}
$$

Dari persamaan substruktur 1 di atas menunjukkan bahwa Iklim Organisasi memiliki arah hubungan positif terhadap Kepuasan Kerja. Ini berarti setiap kenaikan dari variabel Iklim Organisasi akan diikuti dengan peningkatan variabel Kepuasan Kerja.

Dari persamaan substruktur 2 di atas menunjukkan bahwa Iklim Organisasi, dan Kepuasan Kerja memiliki arah hubungan negatif terhadap Turnover Intention. Ini berarti setiap kenaikan dari variabel Iklim Organisasi, dan Kepuasan Kerja akan diikuti dengan penurunan variabel Turnover Intention.

\section{Uji T}

Pengaruh Iklim Organisasi terhadap Kepuasan Kerja standardized coefficients beta sebesar 0,289 dan probabilitas signifikansi $0,000(<0,05)$ artinya terdapat hubungan positif dan signifikan antara Iklim Organisasi terhadap Kepuasan Kerja.

Pengaruh Iklim Organisasi terhadap Turnover Intention memiliki nilai standardized coefficients beta sebesar 0,433 dan probabilitas nilai signifikansi $0,000(<0,05)$ artinya terdapat hubungan negatif dan signifikan antara Iklim Organisasi terhadap Turnover Intention.

Pengaruh Kepuasan Kerja terhadap Turnover Intention memiliki nilai standardized coefficients beta sebesar 0,628 dan probabilitas signifikansi 0,000 $(<0,05)$ artinya terdapat hubungan negatif dan signifikan antara Kepuasan Kerja terhadap Turnover Intention.

\section{Pengujian pengaruh Langsung}

Berdasarkan perhitungan pengaruh langsung, pengaruh Iklim Organisasi terhadap Kepuasan Kerja memiliki hubungan positif sebesar 0,289. Dengan demikian hipotesis H1 yang menyatakan Dimana: 
bahwa Iklim Organisasi berpengaruh signifikan terhadap Kepuasan Kerja, diterima.

Pengaruh Kepuasan Kerja terhadap Turnover Intention memiliki hubungan negatif sebesar - 0,628. Dengan demikian H2 yang menyatakan bahwa Kepuasan Kerja berpengaruh negatif signifikan terhadap Turnover Intention, diterima.

Pengaruh Iklim Organisasi terhadap Turnover Intention memiliki hubungan negatif sebesar - 0,433. Dengan demikian H2 yang menyatakan bahwa Kepuasan Kerja berpengaruh negatif signifikan terhadap Turnover Intention, diterima. Dengan demikian hipotesis H3 yang menyatakan bahwa Iklim Organnisasi berpengaruh negatif signifikan terhadap Turnover Intention, diterima.

\section{Pengujian pengaruh Tidak Langsung}

Berdasarkan perhitungan pengaruh tidak langsung memiliki bobot nilai 0,181, hal ini menunjukkan bahwa Iklim Organisasi yang nyaman dapat menjadi kepuasan kerja bagi karyawan PT. Bank Sulselbar, sehingga dapat menurunkan niat untuk pindah (turnover intention). Dengan demikian maka $\mathrm{H} 4$ yang diajukan dalam penelitian ini, diterima.

\section{Perhitungan Total Pengaruh}

Berdasarkan hasil perhitungan total pengaruh menunjukkan bahwa kombinasi dari variabel Iklim Organisasi dan Kepuasan Kerja berpengaruh negatif terhadap niat untuk pindah (turnover intention) dengan bobot nilai -0,339. Hal ini menunjukkan bahwa lingkungan Iklim Organisasi yang nyaman dan didukung dengan rasa Kepuasan Kerja dari karyawan PT. Bank Sulselbar akan menurunkan niat untuk pindah (turnover intention) karyawan PT. Bank Sulselbar.

\section{Pembahasan}

Berdasarkan hasil uji secara parsial (uji t) pada variabel iklim organisasi $\left(\mathrm{X}_{1}\right)$ terhadap kepuasan kerja $\left(\mathrm{Y}_{1}\right)$, membuktikan bahwa hipotesis pertama $\left(\mathrm{H}_{1}\right)$ yang menyatakan "iklim organisasi berpengaruh positif signifikan terhadap kepuasan kerja" diterima. Berdasarkan hasil analisis regresi, koefisien hubungan antara iklim organisasi dengan kepuasan kerja dengan nilai signifikansi sebesar 0,289 lebih besar dari 0,05 mengindikasikan bahwa iklim organisasi berpengaruh positif signifikan terhadap kepuasan kerja. Arah hubungan yang positif dari hasil uji regresi mengindikasikan dalam setiap peningkatan kualitas iklim organisasi akan diikuti dengan peningkatan kepuasan kerja artinya semakin baik iklim organisasi perusahaan, akan semakin meningkatkan kepuasan kerja karyawan PT. Bank Sulselbar Makassar.

Berdasarkan hasil uji secara parsial (uji t) pada variabel kepuasan kerja $\left(\mathrm{Y}_{1}\right)$ terhadap turnover intention $\left(\mathrm{Y}_{2}\right)$, membuktikan bahwa hipotesis kedua $\mathrm{H} 2$ yang menyatakan "kepuasan kerja berpengaruh negatif signifikan terhadap turnover intention" diterima. Berdasarkan hasil analisis regresi, koefisien hubungan antara kepuasan kerja dengan turnover intention dengan nilai signifikansi sebesar $-0,628$ lebih besar dari 0,05 mengindikasikan bahwa kepuasan kerja berpengaruh secara negatif signifikan terhadap turnover intention. Arah hubungan yang negatif dari hasil uji regresi mengindikasikan dalam setiap peningkatan kepuasan kerja akan diikuti dengan penurunan turnover intention artinya kepuasan kerja akan sangat membantu mengurangi turnover intention karyawan PT. Bank Sulselbar Makassar.

Berdasarkan hasil uji secara parsial (uji t) pada variabel iklim organisasi $\left(\mathrm{X}_{1}\right)$ terhadap turnover intention $\left(\mathrm{Y}_{2}\right)$, membuktikan bahwa hipotesis pertama $\mathrm{H} 3$ yang menyatakan "iklim organisasi 
berpengaruh negatif signifikan terhadap turnover intention" diterima. Berdasarkan hasil analisis regresi, koefisien hubungan antara iklim organisasi dengan kepuasan kerja dengan nilai signifikansi sebesar 0,433 lebih besar dari 0,05 mengindikasikan bahwa iklim organisasi berpengaruh negatif signifikan terhadap turnover intention. Arah hubungan yang negatif dari hasil uji regresi mengindikasikan dalam setiap peningkatan kualitas iklim organisasi akan diikuti dengan menurunnya turnover intention artinya semakin baik iklim organisasi perusahaan, akan semakin menurun turnover intention karyawan PT. Bank Sulselbar Makassar.

Hasil analisis regresi menunjukkan koefisien hubungan antara iklim organisasi dengan turnover intention melalui kepuasan kerja, nilai signifikansi sebesar 0,000 lebih kecil dari 0,05 mengindikasikan bahwa iklim organisasi melalui kepuasan kerja berpengaruh signifikan terhadap turnover intention. Dari hasil tersebut dapat disimpulkan bahwa melalui iklim organisasi yang nyaman akan menciptakan kepuasan kerja bagi karyawan PT. Bank Sulselbar sehingga akan mengurungkan niat untuk berpindah (turnover intention) bagi karyawan PT. Bank Sulselbar.

\section{Kesimpulan}

Iklim organisasi berpengaruh positif signifikan terhadap Kepuasan kerja karyawan PT. Bank Sulselbar secara langsung. Namun Iklim organisasi berpengaruh negatif signifikan terhadap Turnover Intention secara langsung. Untuk variabel Kepuasan kerja berpengaruh negatif signifikan terhadap Turnover Intention karyawan PT. Bank Sulselbar secara langsung. Melalui mediasi Kepuasan Kerja secara tidak langsung Iklim organisasi tetap berpengaruh negatif signifikan terhadap Turnover Intention. Ini menunjukkan bahwa Kualitas dari Iklim Organisasi di PT. Bank Sulselbar dinilai oleh karyawan sudah baik yang akan menciptakan kepuasan kerja bagi karyawan PT. Bank Sulselbar sehingga akan menurunkan niat untuk berpindah (Turnover Intention) bagi karyawan PT. Bank Sulselbar. Diharapkan kepada PT. Bank Sulselbar dapat mempertahankan aspek-aspek yang dinilai dapat meningkatkan iklim organisasi saat ini, dengan adanya sosialisasi yang berkesinambungan terhadap tujuan, visi dan misi perusahaan sangat diperlukan agar karyawan dapat mengetahui dengan jelas arah dan tujuan perusahaan kedepan. Adanya pengelolaan personalia dan promosi karyawan yang berdasarkan kompetensi akan semakin memacu karyawan dalam berprestasi dan dapat meningkatkan kinerjanya. Membina saling percaya antar karyawan, karyawan dengan manager, manager dengan top management, saling mendukung antar anggota organisasi, adanya komunikasi yang sehat dalam organisasi, lingkungan organisasi yang kondusif adalah parameter-parameter yang harus secara terus menerus harus dibina oleh seluruh stakeholders perusahaan dalam rangka mencapai iklim organisasi yang sehat dan baik.

\section{Daftar Pustaka}

Abraham, Rebecca, (1999), "The Impact of Emotional Dissonance on OrganizationalCommitment and Intention to Turnover", The Journal of Psychology, 133(4),441-455

Ahuja, Manju K., Katherine M.Chudoba, Charles J. Kacmar, D. Harrison MCKnight,Joey F. George, 2007, "IT Road Warriors: Balancing WorkFamily Conflict, Job Autonomy, and Work Overload to Mitigate Turnover 
Intentions", MIS Quarterly, Vol.31 No.1, pp.1-17, Maret

Batlis, Nick C., 1980,"The effect of organizational climate on job satisfaction, anxiety, and propensity to leave", The Journal Of Psychology, 104, 233-240

Bretz, Robert D., Jr, John W. Boudreau dan Timothy A. Judge, 1994, "Job searchbehavior of employed managers", Personnel Psychology, 47

Brown, Steven P. dan Robert A. Peterson, 1993, "Antecendents and Consequences of Salesperson Job Satisfaction: Meta-Analysis and Assessment of Causal Effect",Journal of Marketing Research, Vol.XXX. 63-7795

Carmeli, Abraham dan Jacob Weisberg, 2006, "Exploring Turnover Intention among Three Professional Groups of Employees", Human Resource Development International, Vol.9, No.2,191-206, Juni

Carsten, Jeanne, M. dan Paul E. Spector, 1987, "Unemployment, Job Satisfaction, and Employee Turnover: A Meta-Analytic Test of the Muchinsky Model", Journal of Applied Psychology, Vol.72, No.3, 374-381

Chiu, Chou-Kang, Chich-Pen Lin, Yuan Hui Tsai, dan Ching-Yun Hsiao,2005, "Modeling Turnover Intentions and Their Antecendents Using the Locus of Control as a Moderator: A Case of Customer Service Employees", Human Resource Development Quarterly, Vol.16, No.4, Winter
Church, Allan H, 1995, "Manajerial Behaviors and Work Group Climate as Predictors of Employee Outcomes", Human Business Developmnet Quarterly, Vol.6,173- 205.

Churchill, Jr., Gilbert A., Neil M. Ford, dan Orville C. Walker, Jr., 1976, "Organizational Climate and Job Satisfaction in the Salesforce", Journal of Marketing Research, Vol. XIII, November, 323-332

Cotton, John L. \& Tuttle J.M. (1986). Employee Turnover: A MetaAnalysis and Review with Implications for Research. Academy of Management Review, Vol.11, No.1, 55-70.

Desiana, P.M. \& Soetjipto B.W. (2006). Pengaruh Role Stressor dan Persepsi Dukungan Organisasi (Perceived Organizational Support) terhadap Kepuasan Kerja dan Komitmen: Studi Kasus Asisten Dosen FEUI. Usahawan, No.05 TH XXXV, Mei.

Djati, S. Pantja dan Khusaini, 2003, "Kajian Terhadap Kepuasan Kompensasi, Komitmen Dan Prestasi Kerja", Jurnal Manajemen dan Kewirausahaan, Vol 5(1), Maret, 25-41

Downey, H. Kirk dan Don Hellriegel John W. Slocum, Jr., 1975, "Congruence between individual, needs, organizational climate, job satisfaction and performance, Academy of Management Journal, Vol.18, No.196

Fey C.F. \& Beamish W.P. (2001). Organizational climate similarity and Performance: International Joint Ventures in Russia. Organization Studies, 22/5, 853882. 
Fields, Dail, Myra E. Dingman, Paul M. Roman dan Terry C. Blum, 2005, "Exploringpredictors of alternative job changes", Journal of Occupational andOrganizational Psychology, 78, 63-82

Friedlander, Frank dan Newton Margulies,1969, "Multiple Impacts of OrganizationalClimate and Individual Value Systems Upon Job Satisfaction", PersonnelPsychology, 22, 171183

Griffeth, Rodger W., Peter W. Hom, dan Stefan Gaertner, 2000, "A Meta-Analysis ofAntecendents and Correlates of Employee Turnover: Update, Moderator Test, andResearch Implications for Next Millenium", Journal of Management, Vol. 26,No.3, 463-488

Harter J.K., Schmidt F.L., \& Hayes T.L., (2002). Business-UnitLevelRelationship Between Employee Satisfaction, Employee Engagement, andBusiness Outcomes: A Meta-Analysis. Journal of Applied Psychology, Vol.87,No.2, 268-279.

Haryanti, Endang, 2005, Analisis Pengaruh Gaya Kepemimpinan dan IklimOrganisasi Terhadap Kepuasan Kerja dan Kinerja Pegawai KantorKecamatan Gayamsari Pemkot Semarang, Tesis Program Pasca Sarjana Magister Manajemen Universitas Diponegoro (tidak dipublikasikan)

Hom, Peter W. dan Rodger W. Griffeth, 1991, "Structural Equations Modeling Test ofTurnover Theory: CrossSectional and Longitudinal
Analyses", Journal ofApplied Psychology, Vol.76, No.3, 350366

Hwang, Ing-San, Dr. dan Jyh-Huei Kuo, 2006, "Effects of Job Satisfaction and Perceived Alternative Employment Opportunities on Turnover Intention - An Examinationof Public Sector Organizations", The Journal of American Academy ofBusiness, Cambridge, Vol.8, March

Igbaria M. \& Greenhaus, J. H. (1992). Determinants of MIS employees turnover intentions: a structural equation model. Communications of the ACM, 35, pp. 34-51.

Jaramillo, Fernando, Jay Parakash Mulki, and Paul Solomon, 2006, "The role ofethicalclimate on salesperson role stress, job attitudes, turnover intention, and jobperformance",Journal of Personal Selling \& Sales Management, Vol. XXVI,No.3, summer, pp.271-282

Mahajan, Jayashree, Gilbert A. Churchill, Jr., Neil M. Ford, dan Orville C. Walker, Jr., 1984, “A Comparison of the Impact of Organizational Climate on the JobSatisfaction of Manufacturer's Agents and Company Salespeople: An ExploratoryStudy", Journal of Personel Sellings \& Sales Management.

Muchinsky, Paul M., 1977, "Organizational

Communication: Relationships toOrganizational Climate and Job Satisfaction", Academy of ManagementJournal, Vol. 20, No.4, 592-607

Mulki et al. (2006). Effect of ethical climate andsupervisory trust on 
salesperson's job attitudes and intentions to quit. Journal of Personal Selling and Sales Management, Vol.XXVI, No.1, Winter, pp.19-26.

Robbins, Stephens P., 2003, Prilaku Organisasi, Edisi Kesepuluh, Prentice-Hall, Jakarta

Samad S. (2006). Predicting Turnover Intentions: The Case of Malaysian Government Doctors. The Journal of American Academy of Business, Cambridge, Vol.8, No.2, March 99.

Tett, Robert P. dan John P. Meyer, 1993, "Job satisfaction, organizational

commitment,turnover intention, and turnover: path analyses based on meta-analytic findings", Personnel

Psychology, 46

Vandenberg R. J. \& Nelson J.B. (1999). Disaggregating the Motives Underlying Turnover Intentions: When Do Intentions Predict Turnover Behavior?. Human Relations, Vol.52, Oktober, 13131336.

Vardi Y. (2001). The effects of organizational and ethical climate on misconduct at Work. Journal of Business Ethics, 29: 325-337. 